\title{
PENGARUH TEKANAN KEUANGAN TERHADAP PENGHINDARAN PAJAK
}

\author{
Eny Suprapti \\ Program Studi Akuntansi Fakultas Ekonomi dan Bisnis \\ Universitas Muhammadiyah Malang \\ Jl. Raya Tlogomas No. 246 Malang \\ Email: e.suprapti@yahoo.com
}

Abstract

This study examines the effect of Growth, ROA, Leverage, Cashflow nagatif and size on tax avoidance. The testing was held 82 samples. The data obtained from the company's annual report website Indonesian Stock Exchange during the period 2016 and analyzed using Multiple Regresion. The research finding show that ROA negatively affect of tax evaoidance. Other findings indicate leverage positive effect on tax evoidance. ROA is a financial pressure for the company when profitability performance becomes the target that must be achieved and the research results show the negative direction, it can be stated that the sample company is not in a state of financial pressure because the average ROA is lower than the interest rate on deposit. Meanwhile, leverage shows a positive influence on tax evasion. This proves that the sample companies aggressively increased the use of external funding so as to increase tax avoidance.

Key words: financial pressure, tax evoidance, triangle fraud theory

\section{PENDAHULUAN}

Peran penerimaan pajak sebagai sumber penerimaan dalam negeri di Indonesia dari tahun ke tahun menunjukkan angka yang semakin besar. Beberapa tahun terakhir penerimaan dalam negeri dari sektor perpajakan selalu lebih besar dibandingkan penerimaan bukan pajak. Penerimaan dalam negeri yang bersumber dari perpajakan dari tahun 2007 sampai tahun 2016 menunjukkan kisaran 70$80 \%$. Hal ini menggambarkan bahwa pemerintah sangat mengandalkan sumber penerimaan dari sektor pajak, dan akan semakin mengurangi ketergantungan pada sektor lain.

Ketergantungan pemerintah terhadap penerimaan pajak, ternyata belum didukung secara maksimal oleh masyarakat sebagai pembayar pajak. Tax rasio Indonesia tahun 2016 menunjukkan angka 10,6 kurang dari $11 \%$ target pemerintah (Utami, 2017). Angka ini masih sangat rendah dibandingkan negara-negara Asean lainnya, disamping itu angka tax rasio juga didukung penerimaan dari kebijakan tax amnesty. Hal ini membuktikan belum maksimalnya peran masyarakat dalam membayar pajak. Rendahnya tax ratio Indonesia mengindikasi adanya tingkat penghindaran pajak yang tinggi. Indikator lain ditunjukkan dengan besarnya perbedaan tax ratio Indonesia dengan negara-negara Asia yang lain. Tingginya penghindaran pajak juga dibuktikan dengan tingkat kepatuhan wajib pajak badan usaha yang hanya $2,3 \%$ dan wajib pajak pribadi $41,6 \%$ (JawaPos, 2012).

Penghindaran pajak memiliki dampak yang luas bagi Negara dan masyarakat. Dalam perspektif ekonomi dampak penghindaran pajak menimbulkan biaya bagi manajemen, pemegang saham dan masyarakat luas (Lanis dan Richardson, 2012). Bagi pengambil kebijakan informasi penghindaran pajak yang terefleksi dari besarnya beban pajak yang dilaporkan dalam laporan keuangan memberikan gambaran kualitas pelaporan pajak perusahaan.

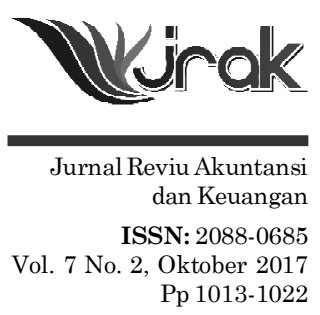




\section{Pengaruh Tekanan Keuangan...}

1014
Pergeseran fenomena penghindaran pajak dari aktivitas legal mengarah pada aktivitas tidak legal (Slemrod dan Yitzhaki, 2002) memberi peluang penelitian dengan landasan teori kecurangan.Teori fraud triangle menyatakan bahwa kecurangan terjadi ketika ada tekanan, kesempatan dan rasionalisasi (Cressey, 1950). Tekanan (pressure) merupakan kesuksesan keuangan yang dapat mendorong produktivitas, inovasi, tetapi juga menyebabkan perilaku curang eksekutif perusahaan. Tekanan yang kuat terhadap kesuksesan keuangan cenderung memberikan dorongan eksekutif perusahaan mengeksploitasi/mengabaikan kontrol regulasi untuk memeroleh keuntungan keuangan (Choo dan Tan, 2007). Dengan demikian dapat dikatakan bahwa manajer yang melakukan kecurangan dilandasi oleh upaya pemanfaatan peluang/kesempatan mengeksploitasi/mengabaikan aturan normative dan regulasi ketika aturan yang ada menghambat/menghalangi pencapaian kesuksesan keuangan mereka.

Penggunaan analisis fraud triangle untuk mendeteksi kecurangan dalam laporan keuangan telah dilakukan dalam penelitian sebelumnya (Turner et al., 2003; Albrecht et al., 2008; Skousen et al., 2008; Lou dan Wang, 2009; Martantya dan Daljono, 2013; Ratmono et al., 2014). Penelitian sebelumnya dilakukan untuk mendeteksi kecurangan laporan keuangan secara umum, belum banyak untuk memprediksi dan menjelaskan kecurangan pajak. Penelitian sebelumnya menjelaskan bahwa penghindaran pajak dilakukan karena ada tekanan untuk mencapai target keuangan (Suprapti, 2016). Keterbatasan penelitian Suprapti (2016) hanya menggunakan Return On Asset (ROA) dan Size sebagai proksi tekanan, sehingga perlu dikembangkan proksi tekanan yang lebih luas untuk memprediksi penghindaran pajak.

Teori Fraud Triangle menyatakan tekanan meliputi tekanan keuangan dan non keuangan. Tekanan keuangan berasal dari internal maupun eksternal. Tekanan keuangan internal direfleksikan dengan besarnya kinerja keuangan yang harus dicapai, diantaranya adalah ROA, pertumbuhan Laba, stabilitas keuangan dan ukuran perusahaan. Sedangkan tekanan keuangan eksternal adalah besarnya tekanan dari kreditur terkait dengan kewajiban perusahaan dalam memenuhi pembayaran utang dan beban bunga yang direfleksikan dengan Leverage.

\section{Pengembangan Hipotesis \\ Size dan penghindaran pajak}

Teori agensi political cost hyipothesis menyatakan bahwa perusahaan besar menanggung biaya politik yang lebih tinggi dibanding perusahaan kecil. Biaya politik terefleksi pada pembayaran pajak atau tarif efektif pajak yang lebih tinggi (Zimmerman, 1983). Perusahaan besar memiliki kemampuan untuk mencapai profitabilitas yang tinggi. Karena itu, pemerintah memberikan perhatian dan pengawasan lebih kepada perusahaan besar. Oleh karena itu, perusahaan dengan kekuasaannya berusaha untuk mencari strategi mengurangi pembayaran pajaknya. Dengan demikian perusahaan besar cenderung menghindari tanggungjawab pajaknya (Kim dan Limpaphayom, 1998).

Teori Fraud Triangle menyatakan bahwa kecurangan dapat dilakukan karena adanya tekanan (Choo dan Tan, 2007). Tekanan keuangan adalah kesuksesan keuangan yang harus dicapai oleh perusahaan. Kesuksesan keuangan perusahaan dapat ditunjukkan dari ukuran perusahaan. Bagi perusahaan publik ukuran perusahaan, laba dan pertumbuhan laba merupakan informasi penting yang menjadi pertimbangan untuk disampaikan, karena banyak pihak yang berkepentingan untuk pengambilan keputusan. Secara periodik informasi keuangan diatas menjadi bahan penilaian dan ulasan dari berbagai pihak dan media, hal ini tentu menjadi tekanan bagi perusahaan untuk bisa mencapainya.

Penelitian penghindaran pajak dikaitkan dengan ukuran perusahaan dilakukan oleh Kim dan Limpaphayom (1998) dan hasilnya ada hubungan negative antara ukuran perusahaan dengan penghindaran pajak. Kontradiktif dengan 
temuan Zimmerman (1983) yang menyatakan ada hubungan positif antara ukuran perusahaan dengan pajak di Amerika, artinya perusahaan besar cenderung membayar pajak lebih besar dibanding perusahaan kecil. Senada dengan Zimmerman, Wu et al. (tanpa tahun) menemukan adanya hubungan positif antara ukuran perusahaan dan Effective Tax rates pada perusahaan yang dikendalikan secara privat. Disisi lain, Salamon dan Siegfried (1977) berargumentasi bahwa perusahaan besar memiliki kemampuan ekonomi dan power politik yang lebih besar dibanding perusahaan kecil, karena itu perusahaan besar memiliki kemampuan untuk menghindari beban pajak. Temuan Porcano (1986) mendukung pernyataan Salamon dan Siegfried (1977), ada hubungan antara ukuran perusahaan dan ETR menggunakan rasio pajak penghasilan kini terhadap laba sebelum pajak dan item luar biasa.

$\mathrm{H}_{1}$ : Size berpengaruh positif terhadap penghindaran pajak

\section{Target keuangan dan penghindaran pajak}

ROA merupakan ukuran variabel target keuangan. Return On Asset (ROA) menunjukkan seberapa efisien pengelolaan aset perusahaan. ROA merupakan salah satu ukuran keberhasilan operasional yang banyak digunakan (Skousen et al., 2008). ROA juga menjadi indikator utama dalam penentuan bonus bagi manajemen, hal ini dapat mendorong manajemen melakukan kecurangan ketika target keuangan tidak tercapai (Oktaviani et al., 2014). ROA yang dicapai tahun sebelumnya akan menjadi target keberhasilan keuangan manajemen di tahun-tahun berikutnya (Martantya dan Daljono, 2013). Semakin besar ROA yang dicapai semakin besar tekanan untuk mencapainya pada periode berikutnya. Manajemen yang diberi amanah untuk mengelola perusahaan akan berupaya untuk mencapai target kinerja keuangan yang ditetapkan. Semakin besar kinerja keuangan yang harus dicapai semakin besar tekanan bagi manajemen. Oleh karena itu, manajemen akan berupaya untuk mencapai target kinerja keuangan dengan cara melakukan kecurangan, diantaranya dengan melakukan penghindaran pajak yang diharapkan dapat meningkatkan laba dan ROA. Target keuangan adalah tekanan berlebihan pada manajemen untuk mencapainya. Pada perusahaan publik pencapaian laba dari tahun sebelumnya menjadi informasi yang baik bagi berbagai pihak terutama investor, disamping itu kewajiban mencapai kinerja keuangan yang stabil atau meningkat harus dipenuhi untuk tetap terdaftar atau masuk perusahaan publik papan atas di Bursa Efek Indonesia. Untuk itu dimungkinkan perusahaan melakukan manipulasi beban pajak untuk mencapai target keuangan yang dicapai. Oleh karena itu hipotesis yang diajukan dalam penelitian ini adalah:

$\mathrm{H}_{2}$ : Target keuangan berpengaruh positif terhadap penghindaran pajak

\section{Tekanan eksternal dan Penghindaran pajak}

Tekanan eksternal merupakan tekanan yang berlebihan bagi manajemen untuk memenuhi harapan atau persyaratan tertentu kepada pihak ketiga. Perusahaan yang memenuhi kebutuhan pendanaan melalui utang, maka terjadi tekanan untuk memenuhi kewajiban melunasi dan membayar beban bunga. Leverage menunjukkan besarnya sumber pendanaan utang untuk melakukan investasi. Semakin tinggi leverage semakin tinggi seumber pendanaan dari utang dan risiko kredit yang juga tinggi. Pada kondisi risiko yang tinggi, manajemen menghadapi masalah likuiditas untuk memenuhi kewajibannya. Manajemen berupaya memberikan informasi yang baik tentang kondisi likuiditasnya, untuk itu manajemen membuat keputusan menghindari pajak untuk meningkatkan cashflow. Berdasarkan argumentasi tersebut, maka diajukan hipotesis sebagai berikut:

$\mathrm{H}_{3}$ : Leverage berpengaruh positif terhadap penghindaran pajak 


\section{Pengaruh Tekanan Keuangan...}

1016

\section{Stabilitas keuangan dan penghindaran pajak}

Stabilitas keuangan menggambarkan keadaan keuangan perusahaan dari kondisi stabil. Stabilitas keuangan perusahaan menghadapi risiko oleh keadaan ekonomi, industri, persaingan dan situasi operasi perusahaan yang menekan manajemen untuk memertahankan stabilitas keuangan. Pertumbuhan laba memberikan gambaran stabilitas keuangan perusahaan. Manajemen memiliki kebutuhan untuk menyampaikan informasi kinerja yang baik. Ketika pertumbuhan laba mengalami penurunan, manajemen mengalami tekanan untuk memertahankan atau meningkatkan. Manajemen akan melakukan penghindaran pajak sebagai upaya menghemat pembayaran beban pajak sehingga dapat meningkatkan laba. Berdasarkan argumentasi tersebut, maka diajukan hipotesis sebagai berikut:

$\mathrm{H}_{4}$ : stabilitas keuangan berpengaruh negatif terhadap penghindaran pajak

\section{Arus Kas negatif dan penghindaran pajak}

Arus kas memberikan informasi stabilitas keuangan perusahaan dan banyak digunakan sebagai pembanding kinerja antar perusahaan. Pada saat perusahaaan mengalami arus kas negatif, maka keadaan ini akan menjadi perhatian investor untuk meramalkan kinerja perusahaan pada masa yang akan datang (Ratmono et al., 2014). Keadaan arus kas negatif menunjukkan perusahaan dalam kondisi illikuid dan mengalami tekanan untuk memperbaiki kondisi keuangan perusahaan. Ketidakmampuan perusahaan menghasilkan arus kas positif akan mendorong terjadinya kecurangan keuangan (Skousen et al., 2008) dan berhubungan positif dengan kecurangan laporan keuangan (Lou dan Wang, 2009). Pada kondisi mengalami tekanan dan kebutuhan untuk memerbaiki kondisi kas, manajemen akan melakukan penghindaran pajak sehingga dapat menghemat kas dan dapat memerbaiki likuiditas perusahaan. Berdasarkan argumentasi tersebut, maka diajukan hipotesis sebagai berikut:

$\mathrm{H}_{5}$ : Arus kas negatif berpengaruh positif terhadap penghindaran pajak

\section{METODE}

\section{Populasi dan sampel}

Populasi penelitian adalah perusahaan publik, alasan pemilihan perusahaan publik sebagai populasi adalah keterbukaan informasi lebih besar sehingga lebih mudah memeroleh data penelitian. Jumlah populasi sebanyak 354 perusahaan selama 1 tahun dan sampel dipilih yang memenuhi kriteria menjadi sampel yaitu perusahaan bukan perusahaan keuangan, pelayaran dan property; Efective Tax Rate $(\mathrm{ETR})<1$; perusahaan tidak mengalami Rugi. Data terkait dengan variabel penghindaran pajak, target keuangan, size, stabilitas keuangan, leverage dan Arus kas negatif diperoleh website PT BursaEfek Indonesia www.idx.co.id

Pengukuran variabel penghindaran pajak menggunakan Efective Tax Rate (ETR) (Frank et al., 2009) yaitu rasio beban pajak terhadap laba sebelum pajak (Zimmerman, 1983; D.Dyreng et al., 2010; Hanlon dan Heitzman, 2010; Minnick dan Noga, 2010; Huseynov dan Klamm, 2012). Sementara beberapa variabel yang menimbulkan tekanan mendorong individu maupun organisasi berbuat curang adalah stabilitas keuangan, tekanan eksternal, kebutuhan keuangan individu dan target keuangan. Tekanan keuangan adalah kesuksesan keuangan yang harus dicapai oleh perusahaan (Choo dan Tan, 2007) yang ditunjukkan oleh target keuangan, size, stabilitas keuangan, tekanan eksternal, Arus kas negatif. Pengukuran target keuangan menggunakan ROA (Wahab dan Holand, 2012; Martantya dan Daljono, 2013; Oktaviani et al., 2014; Ratmono et al., 2014), Size menggunakan ln asset, Stabilitas keuangan (Sikka, 2010; IAPI, 2013), menggunakan pertumbuhan laba, tekanan eksternal diproksi dengan leverage (Skousen et al., 2008; Lou dan Wang, 2009) dan arus kas negatif diukur dengan dummy variabel dengan 
nilai 1 jika arus kas dua tahun berturut-turut negatif dan sebaliknya (Lou dan Wang, 2009)

\section{Analisis data}

Model penelitian diregresi dengan menggunakan bantuan SPSS versi 23. Analisis data yang dilakukan meliputi statistik deskriptif, pengujian $\mathrm{R}^{2}$ dan pengujian hipotesis. Adapun model penelitian menggunakan Effective Tax Rate (ETR) sebagai pengukur penghindraan pajak sesuai penelitian Suprapti (2016) dan Dyreng et al. (2008). Adapun model penelitian adalah sebagai berikut:

$\mathrm{PP}=\alpha 0+\beta_{1} \mathrm{StaK}+\hat{\mathrm{a}}_{2} \mathrm{Size}+\hat{\mathrm{a}}_{3} \mathrm{ROA}+\hat{\mathrm{a}}_{4} \mathrm{Lev}+\hat{\mathrm{a}}_{5} \mathrm{Kasn}$

Dimana:

$\mathrm{PP} \quad=$ Penghindaran Pajak diukur dengan membandingkan beban pajak terhadap Laba sebelum Pajak

StaK = Stabilitas Keuangan diukur dengan pertumbuhan laba

Size = Ukuran perushaan dihitung dari Ln total aset

ROA = Return On Asset yang merupakan profitabilitas yaitu perbandingan laba bersih setelah pajak dibandingkan total Aset

Lev = Leverage yaitu rasio utang jangka panjang terhadap total ekuitas

Kasn $=$ Kas negatif diukur dengan dummy variabel dengan nilai 1 jika arus kas dua tahun berturut-turut negatif dan sebaliknya

\section{HASIL PENELITIAN DAN PEMBAHASAN}

Penelitian ini menggunakan sampel perusahaan go public sektor manufaktur yang terdaftar di Bursa Efek Indonesia (BEI) tahun 2016. Berdasarkan distribusi pengambilan sampel, jumlah sampel dalam penelitian ini sebanyak 82 perusahaan dari total populasi penelitian sebanyak 144 perusahaan. Penelitian ini menggunakan 6 variabel, terdiri dari variabel dependen yaitu tax avoidance, variabel independen terdiri dari Pertumbuhan laba, leverage, size, ROA dan Cashflow negatif. Hasil statistik deskriptif dalam penelitian ini berupa nilai minimum, nilai maksimum, nilai rata-rata serta standar deviasi.

\begin{tabular}{lrrrrrrrr}
\hline & N & Minimum & Maximum & Mean & $\begin{array}{r}\text { Std. } \\
\text { Deviation }\end{array}$ & Variance & Skewness \\
\cline { 2 - 8 } & Statistic & Statistic & Statistic & Statistic & Statistic & Statistic & Statistic & $\begin{array}{c}\text { Std. } \\
\text { Error }\end{array}$ \\
\hline ETR & 82 &, 02 & 85,37 & 28,9413 & 16,03932 & 257,260 &, 952 &, 266 \\
GPROFIT & 82 & $-12,80$ & 32,82 & 6,8561 & 9,32021 & 86,866 &, 184 &, 266 \\
LEV & 82 & 5,23 & 93,32 & 42,3301 & 19,90546 & 396,227 &, 156 &, 266 \\
SIZE & 82 & 12,36 & 30,25 & 22,8313 & 5,37023 & 28,839 &,- 372 &, 266 \\
ROA & 82 &, 00 & 37,20 & 7,3239 & 7,34993 & 54,021 & 1,798 &, 266 \\
CFN & 82 &, 00 & 1,00 &, 0244 &, 15521 &, 024 & 6,282 &, 266 \\
Valid N & 82 & & & & & & & \\
(listwise) & & & & & & &
\end{tabular}

Tabel: 1 .

\section{Statistik Deskriptif}

Effective Tax Rate (ETR) sebagai indikator penghindaran pajak merupakan rasio beban pajak terhadap laba sebelum pajak. Rasio ini menggambarkan besarnya prosentase pajak kini dan pajak tangguhan dari laba sebelum pajak perusahaan. Dari tabel 1 menggambarkan rata-rata ETR sebesar 28,94\%, nilai minimum 0,02 \% dan nilai maksimum sebesar 85,37\%, serta standar deviasi 16,04\% yang menunjukkan variasi sebaran data. Rata-rata ETR sebesar 28,94\% dan standar deviasi sebesar 16,9\% menggambarkan kemampuan sebagian perusahaan membayar pajak masih dibawah tarif yang berlaku sebesar $25 \%$. 


\section{Pengaruh Tekanan Keuangan...}

1018

Tabel 2 Model Summary

Tabel 3 Hasil analisis ANOVA
Rata-rata pertumbuhan laba bersih perusahaan manufaktur di tahun 2016 sebesar 6,86 \% dengan standar deviasi 9,32 \% menggambarkan keragaman pertumbuhan laba yang tinggi pada perusahaan sampel. Rata-rata leverage perusahaan sampel 42,33\% menunjukkan sumber pendanaan perusahaan sampel hampir setengahnya berasal dari pihak luar berupa utang. Standar deviasi leverage 19,90 \% menggambarkan besarnya penggunaan pendanaan dari eksternal pada perusahaan sampel cukup beragam. Rata-rata size perusahaan cukup besar, menunjukkan kemampuan perusahaan secara ekonomi cukup besar dan seharusnya kemampuan membayar pajak juga seimbang dengan kemampuan ekonomisnya. Indikator kedua adalah ROA, besarnya ROA tahun sebelumnya menunjukkan target keuangan yang harus dicapai. Rata-rata ROA tahun lalu dari tahun penelitian sebesar 0,09 dengan standar deviasi 0,074 serta nilai minimum 0,001 dan nilai maksimum 0,4. Besarnya standar deviasi yang relatif kecil menggambarkan ROA perusahaan sampel relatif sama. Nilai rata-rata cashflow negatif perusahaan hanya 0,04 menunjukkan tidak banyak perusahaan yang mengalami masalah cashflow.

\section{Hasil pengujian hipotesis dan pembahasan}

Penelitian ini bertujuan untuk memprediksi penghindaran pajak dipengaruhi variabel pertumbuhan laba, leverage, size, ROA dan cashflow negatif. Ketepatan fungsi regresi sampel merupakan hal penting untuk menaksiir nilai aktual, untuk itu perlu diukur Goodness of fitnya. Secara statistik Goodness of fit dapat diukur dari koefisien determinasi, nilai statistik F dan nilai statistik t. Berdasarkan hasil pengujian dapat digambarkan dari tabel dibawah ini:

\begin{tabular}{ccccc}
\hline Model & R & R Square & Adjusted R Square & $\begin{array}{c}\text { Std. Error of the } \\
\text { Estimate }\end{array}$ \\
\hline 1 &, $433^{\text {a }}$ &, 187 &, 126 & 12,263 \\
\hline a. Predictors: (Constant), CFN, LEV, SIZE, GPROFIT, ROA
\end{tabular}

Dari tabel diatas ditunjukkan nilai Adjusted $\mathrm{R}^{2}$ sebesar $12,6 \%$, artinya variasi penghindaran pajak dapat dijelaskan oleh variasi pertumbuhan laba, leverage, size, ROA dan cashflow negatif sebesar $12,6 \%$. Sisa variabel yang belum terjelaskan dalam penellitian ini disebabkan oleh faktor lain diluar model penelitian ini.

\begin{tabular}{llrrrrr}
\hline \multicolumn{2}{c}{ Model } & $\begin{array}{c}\text { Sum of } \\
\text { Squares }\end{array}$ & df & Mean Square & F & Sig. \\
\hline Regression & 3060,095 & 5 & 612,019 & 3,963 & ,003 \\
1 & Residual & 10038,969 & 65 & 154,446 & & \\
& Total & 13099,064 & 70 & & & \\
\hline a. Dependent Variable: ETR \\
b. Predictors: (Constant), CFN, LEV, SIZE, GPROFIT, ROA
\end{tabular}

Hasil pengujian ANOVA atau F test diperoleh nilai sebesar 3,963 dengan probabilitas 0,003 lebih kecil dari 0,05, maka model regresi dapat digunakan untuk memprediksi penghindaran pajak atau dapat dikatakan bahwa pertumbuhan laba, leverage, size, ROA dan cashflow negatif secara bersama-sama berpengaruh terhadap penghindaran pajak

\begin{tabular}{|c|c|c|c|c|c|c|}
\hline & \multirow[t]{2}{*}{ Model } & \multicolumn{2}{|c|}{$\begin{array}{l}\text { Unstandardized } \\
\text { Coefficients }\end{array}$} & \multirow{2}{*}{$\begin{array}{c}\begin{array}{c}\text { Standardized } \\
\text { Coefficients }\end{array} \\
\text { Beta } \\
\end{array}$} & \multirow[t]{2}{*}{$\mathbf{t}$} & \multirow[t]{2}{*}{ Sig. } \\
\hline & & B & Std. Error & & & \\
\hline \multirow{6}{*}{1} & (Constant) & 19,737 & 9,224 & & 2,140 & ,036 \\
\hline & GPROFIT & , 135 & , 173 & ,088 &, 780 & ,438 \\
\hline & LEV & ,209 & ,086 & ,290 & 2,432 & ,018 \\
\hline & SIZE & ,070 & 298 &, 027 &, 234 & ,815 \\
\hline & ROA &,- 497 & 209 &,- 275 & $-2,375$ & ,021 \\
\hline & $\mathrm{CFN}$ & 8,949 & 9,232 & , 109 &, 969 & ,336 \\
\hline
\end{tabular}


Berdasarkan hasil pengujian pada tabel 4 dapat dijelaskan nilai statistik t dari masing-masing hubungan variabel pertumbuhan laba, leverage, size, ROA dan cashflow negatif secara individu terhadap penghindaran pajak. Tabel diatas menunjukkan nilai signifikansi dan koefisien regresi sebagai dasar pengambilan kesimpulan hasil penelitian, arah dan besarnya nilai koefisien regresi.

\section{Pertumbuhan Laba dan Penghindaran Pajak}

Hasil pengujian pengaruh pertumbuhan laba terhadap penghindaran pajak menunjukkan koefisien regresi sebesar 0,135 dengan probabilitas sgnifikansi 0,438 lebih dari 0,05 yang berarti tidak signifikan pada á $=0,05$. Hal ini mengindikasikan bahwa hipotesis $1\left(\mathrm{H}_{1}\right)$ yang menyatakan bahwa pertumbuhan laba berpengaruh negatif terhadap penghindaran pajak ditolak. Hasil penelitian dapat dijelaskan dengan argeumentasi sebagai berikut, pertama pertumbuhan laba merupakan refleksi dari stabilitas keuangan perusahaan. Stabilitas Keuangan adalah keadaan yang menggambarkan kondisi keuangan perusahaan dari kondisi stabil. Ketika financial stability perusahaan berada dalam kondisi yang terancam, maka manajemen akan melakukan berbagai cara agar financial stability perusahaan terlihat baik. Pada kasus di mana perusahaan mengalami pertumbuhan industri di bawah rata-rata, manajemen sangat mungkin menggunakan manipulasi laporan keuangan untuk meningkatkan tampilan perusahaan (Skousen et al., 2009), dalam hal ini penghindaran pajak memainkan peranan penting untuk menampilkan pertumbuhan yang stabil. Ketika pertumbuhan laba menurun, perusahaan akan berupaya untuk meningkatkan laba melalui pengurangan atau penghematan pajak. Fakta bahwa dari jumlah sampel perusahaan, hanya $39 \%$ yang pertumbuhan labanya tidak stabil. Argumentasi kedua, teori Fraud Triangle menyatakan bahwa kinerja keuangan yang tinggi menjadi tekanan untuk mencapai atau mempertahankan kinerja tersebut. Sebagian besar data pertumbuhan laba perusahaan sampel diatas rata-rata artinya dalam kondisi stabil. Hal ini menggambarkan kinerja pertumbuhan laba perusahaan bukan merupakan target yang menjadi tekanan keuangan bagi perusahaan.

\section{Leverage dan Penghinndaran Pajak}

Hasil pengujian pengaruh leverage terhadap penghindaran pajak menunjukkan koefisien regresi sebesar 0,209 dengan probabilitas sgnifikansi 0,018 kurang dari 0,05 yang berarti signifikan pada $\alpha=0,05$. Hal ini mengindikasikan bahwa hipotesis $2\left(\mathrm{H}_{2}\right)$ yang menyatakan bahwa leverage berpengaruh positif terhadap penghindaran pajak diterima. Penggunaan utang sebagai salah sumber dana berdampak pada pembayaran bunga sebagai pengurang laba kena pajak, dengan demikian beban bunga menjadi insentif pajak bagi perusahaan. Hal tersebut membawa implikasi meningkatnya penggunaan utang oleh perusahaan (Prakosa, 2014). Hasil penelitian ini mendukung penelitian Prakosa (2014), (Waluyo et al., 2015) yang membuktikan leverage berpengaruh terhadap penghindaran pajak.

\section{Size dan Penghindaran Pajak}

Hasil pengujian pengaruh Size terhadap penghindaran pajak menunjukkan koefisien regresi sebesar 0,070 dengan probabilitas sgnifikansi 0,443 lebih dari 0,815 yang berarti tidak signifikan pada $\alpha=0,05$. Hal ini mengindikasikan bahwa hipotesis $3\left(\mathrm{H}_{3}\right)$ yang menyatakan bahwa size berpengaruh positif terhadap penghindaran pajak ditolak. Perusahaan besar dengan kekuasaannya berusaha untuk mencari strategi mengurangi pembayaran pajaknya. Dengan demikian perusahaan besar cenderung menghindari tanggungjawab pajaknya (Kim dan Limpaphayom, 1998). Penelitian ini tidak mendukung teori Kim dan Limpaphayom (1998) hal ini dapat dapat dijelaskan bahwa sebesar $82 \%$ perusahaan sampel memiliki size dibawah rata-rata, hal ini menggambarkan perusahaan tidak dalam posisi memiliki kekayaan yang besar dan tidak mengalami tekanan untuk mencapai target size. 
Pengaruh Tekanan Keuangan...
Oleh karena itu perusahaan tidak memanfaatkan strategi untuk mempertahankan atau meningkatkan kekayaan melalui penghindaran pajak.

\section{ROA dan penghindaran Pajak}

Hasil pengujian pengaruh ROA terhadap penghindaran pajak menunjukkan koefisien regresi sebesar -0,497 dengan probabilitas signifikansi 0,021 kurang dari 0,05 yang berarti signifikan pada $\alpha=0,05$. Hal ini mengindikasikan bahwa hipotesis $4\left(\mathrm{H}_{4}\right)$ yang menyatakan bahwa ROA berpengaruh positif terhadap penghindaran pajak ditolak. Koefisien negatif menunjukkan bahwa semakin tinggi ROA maka semakin rendah penghindaran pajak yang dilakukan perusahaan. Hasil penelitian ini mendukung penelitian Zimmerman (1983) yang menyatakan bahwa perusahaan besar memiliki efefective tax rate lebih besar. Hal ini dilandasi argumentasi bahwa tax shield perusahaan dalam jangka pendek tidak berubah atau tetap. Pada periode dimana perusahaan mengalami kesuksesan keuangan, maka cashflow, profit dan pajak perusahaan akan lebih tinggi, sementara tax shield tidak mengalami peningkatan secara proporsional. Argumentasi hasil penelitian dapat dijelaskan bahwa ROA yang dicapai tahun sebelumnya akan menjadi target keberhasilan keuangan manajemen di tahun-tahun berikutnya (Martantya dan Daljono, 2013). Semakin besar ROA yang dicapai semakin besar tekanan untuk mencapainya pada periode berikutnya. Hasil statistik deskriptif rata-rata ROA pada perusahaan sampel sebesar 7,32\% merupakan capaian kinerja profitabilitas yang rendah jika dibandingkan dengan suku bunga deposito tahun 2016 sebesar 7,75 \% (ekonomi, 2016). Dengan demikian dapat dijelaskan bahwa perusahaan sampel tidak dalam kondisi menghadapi tekanan untuk mencapai kinerja ROA.

\section{Cashflow Negatif dan Penghindaran Pajak}

Hasil pengujian pengaruh cashflow negatif terhadap penghindaran pajak menunjukkan koefisien jalur sebesar 8,949 dengan p-value 0,330 kurang dari 0,05 yang berarti tidak signifikan pada $\alpha=0,05$. Hal ini mengindikasikan bahwa hipotesis $5\left(\mathrm{H}_{5}\right)$ yang menyatakan bahwa cashflow negatif berpengaruh positif terhadap penghindaran pajak ditolak.

Keadaan arus kas negatif menunjukkan perusahaan dalam kondisi illikuid dan mengalami tekanan untuk memperbaiki kondisi keuangan perusahaan. Ketidakmampuan perusahaan menghasilkan arus kas positif akan mendorong terjadinya kecurangan keuangan (Skousen et al., 2008) dan berhubungan positif dengan kecurangan laporan keuangan (Lou dan Wang, 2009). Pada kondisi mengalami tekanan dan kebutuhan untuk memerbaiki kondisi kas, manajemen akan melakukan penghindaran pajak sehingga dapat menghemat kas dan dapat memerbaiki likuiditas perusahaan. Hipotesis yang tidak terdukung dapat dijelaskan bahwa kondisi keuangan perusahaan tidak mengalami masalah keuangan. Data penelitian membuktikan bahwa dari 82 sampel perusahaan sebagian cashflownya positif

\section{SIMPULAN}

Praktik penghindaran pajak dapat dipahami dari dimensi tekanan keuangan. Fenomena penghindaran pajak yang bergeser kearah tindakan tidak legal, mendorong/memotivasi perilaku penghindaran pajak ketika ada tekanan keuangan internal maupun eksternal. Hasil penelitian menunjukkan penghindaran pajak dipengaruhi ROA dan leverage. ROA merupakan tekanan keuangan bagi perusahaan ketika kinerja profitabilitas menjadi target yang harus dicapai dan hasil penelitian menunjukkan arah negatif, maka dapat dinyatakan bahwa perusahaan sampel tidak dalam kondisi mengalami tekanan keuangan karena rata-rata ROA yang rendah dibanding tingkat bunga deposito. Sementara, leverage menunjukkan pengaruh positif terhadap penghindaran pajak. Hal ini membuktikan bahwa per- 
usahaan sampel secara agresif meningkatkan penggunaan dana dari pihak eksternal sehingga meningkatkan penghindaran pajak.

\section{DAFTAR PUSTAKA}

Albrecht, W. S., C. Albrecht, dan C. C. Albrecht. 2008. "Current Trends in Fraud and its Detection". Information Security Journal: A Global Perspective, Vol. Volume 17 Issue 1, January 2008 No., hlm: 2-12

Choo, F., dan K. Tan. 2007. "An"American Dream" Theory of corporate exectutive Fraud". Accounting forum, Vol. 31, No., hlm: 203-2015.

Cressey, D. R. 1950. "The Criminal Violation of Financial Trust". American Sociological Review, Vol. 15 No. 6, No., hlm: 738-743.

D.Dyreng, S., M. Hanlon, dan E. L.Maydew. 2010. "The Effect of Executives on Corporate Tax Avoidance". The Accounting Review, Vol. 85 No 4, No., hlm: 1163-1189.

ekonomi, P. s. i. 2016. "8 Bank Dengan Bunga Deposito Tertinggi Di Indonesia". [diakses pada.

Frank, M. M., L. J. Lynch, dan S. O. Rego. 2009. "Tax Reporting Aggressiveness and Its Relation to Aggressive Financial Reporting". The Accounting Review, Vol. 84, No., hlm: 467-496.

Hanlon, M., dan S. Heitzman. 2010. "Review of tax research". Journal of Accounting and Economics, Vol. 50, No., hlm: 127-178.

Huseynov, F., dan B. K. Klamm. 2012. "Tax avoidance, tax management and corporate social responsibility". Journal of Corporate Finance, Vol., No., hlm: 804827.

IAPI. 2013. "Standar Profesional Akuntan Publik". Jakarta. Penerbit Salemba Empat.

JawaPos. 2012. "Aparat diajak tagih tunggakan”. [diakses pada 25 Oktober 2012].

Kim, K. A., dan P. Limpaphayom. 1998. "Taxes and Firm Size in Pacific-Basin Emerging Economies “. Journal of International Accounting, Auditing \& Taxation, Vol. 7 (1), No., hlm: 47-68.

Lanis, R., dan G. Richardson. 2012. "Corporate social responsibility and tax aggressiveness:

An empirical analysis

“. Journal Account Public, Vol. 31 No., hlm: 86-106.

Lou, Y.-I., dan M.-L. Wang. 2009. "Fraud Risk Factor of Fraud Triangle Assesing The Likelihood of Fraudulent Financial Reporting". Journal of Business \& Economic Research, Vol. 7 (2), No., hlm: 61-78.

Martantya, dan Daljono. 2013. "Pendeteksian Kecurangan Laporan Keuangan melalui Faktor RisikoTekanan dan Peluang “. Diponegoro Journal Of Accounting, Vol. 2 No 2, No., hlm: 1-12.

Minnick, K., dan T. Noga. 2010. "Do Corporate Governance Characteristic influence tax management ?". Journal of Corporate Finance, Vol. 16, No., hlm: 703-718.

Oktaviani, E., G. Karyawati, dan N. Arsyad. Year. "Factors Affecting Financial Statement Fraud: Fraud Triangle Approach". Artikel dipresentasikan pada Economic \& Business Research Festival, di Salatiga.

Prakosa, K. B. S. N. A. M. L. Year. "Pengaruh Profitabilitas, Kepemilikan Keluarga, Dan Corporate Governance Terhadap Penghindaran Pajak Di Indonesia". Artikel dipresentasikan pada Simposium Nasional Akuntansi, di Mataram 
Pengaruh

Tekanan

Keuangan...

1022
Ratmono, D., Y. A. D, dan A. Purwanto. Year. "Dapatkah teori fraud triangle menjelaskan kecurangan dalam laporan keuangan". Artikel dipresentasikan pada Simposium Nasional Akuntansi, di Mataram, Lombok.

Sikka, P. 2010. "Smoke and mirrors: Corporate social responsibility and tax avoidance". Accounting forum, Vol. 34, No., hlm: 153-168.

Skousen, C. J., K. R. Smith, dan C. J. Wright. 2008. Detecting and Predicting Financial Statement Fraud: The Effectiveness Of The Fraud Triangle And SAS No. 99: http://ssrn.com/abstract=1295494.

Skousen, C. J., K. R. Smith, dan C. J. Wright. 2009. "Detecting and predicting financial statement fraud: The effectiveness of the fraud triangle and SAS No. 99". Advances in Financial Economics, Vol. 13, No. 1, hlm: 53-81.

Slemrod, J., dan S. Yitzhaki. 2002. Handbook of Public Economics. In Tax Avoidance, Evasion, and Administration

Elsevier Science B.V.

Suprapti, E. 2016. "Pengaruh struktur kepemilikan,tekanan keuangan, kesempatan dan rasionalisasi keuangan dengan corporate governance sebagai variabel pemoderasi”, Akuntansi, Universitas Brawijaya Malang.

Turner, J. L., T. J. Mock, dan R. P. Srivastava. 2003. An Analysis of the Fraud Triangle, 1-33.

Utami, S. S. 2017. "Sri Mulyani Kecewa Tax Ratio 2016 di Bawah 11\%". Metrotvnews.com.

Wahab, N. S. A., dan K. Holand. 2012. "Tax Planning, Corporate Governance and Equity Value". The British Accounting Review, Vol. 44, No., hlm: 111-124.

Waluyo, T. M., Y. M. Basri, dan Rusli. Year. "Pengaruh Return on Asset, Leverage, Ukuran Perusahaan, Kompensasi Rugi Fiskal dan Kepemilikan Institusi Terhadap Penghindaran Pajak". Artikel dipresentasikan pada Simposium Nasional Akuntansi, di Medan.

Wu, L., Y. Wang, P. Gilis, dan W. Luo. tanpa tahun. "State Ownership. Tax status, and Size Effect of Effective Tax Rate in China". JEL, Vol., No., hlm: 1-28.

Zimmerman, J. L. 1983. "Taxes and Firm Size". Journal of Accountmg and Economics, Vol. 5, No., hlm: 119-149. 